\title{
NOTES ON SPIDERS FROM PUERTO RICO ${ }^{1}$
}

\author{
By Elizabeth B. Bryant \\ Museum of Comparative Zoölogy
}

Recently the Museum of Comparative Zoölogy received a small vial of spiders from the Luquillo Mountains in the eastern part of Puerto Rico, collected by Mr. Harry Beatty, at about 3,000 feet elevation. It is a section of the island from which Dr. Petrunkevitch had little material when he published "The Spiders of Porto Rico," 1929-1930, so it is not surprising that among the fourteen species, four are new and three others have never been reported from the island before.

The following is a list of the species found. The asterisk $\left({ }^{*}\right)$ denotes the first time the species has been recorded from the island.

\section{Family OönOPID}

o $\quad$ Stenoönops portoricensis Petr.

Family Therididd

o $q$ Allodipœna dianæ spec. nov.

\& Conopistha argyrodes nephila (Tacz.)

*o Rhomphaa fictilum (Hentz)

Family LinyphIId

Erigone?

Family Argiopid ж

万. Argiope argentata (Fabr.)

ô Tetragnatha parva spec. nov.

Family Tноміsid же

* ${ }^{\top}$ Misumenops bellulus (Banks)

Family Clubionide

q Clubiona desecheonis Petr.

+ Wulfila immaculata Banks

1 Published by a grant from the Museum of Comparative Zoology at Harvard College. 


\section{Family Salticide \\ $q$ Agobardus blandus spec. nov. \\ ot $q$ Habronattus pretiosus spec. nov. \\ Hentzia antillanus Bryant \\ * ${ }^{\top} \quad$ Sidusa mona Bryant \\ Family TherIdIID \\ Genus Allodipœna gen. nov.}

Cephalothorax almost as wide as long, anterior margin about half the greatest width, cephalic portion high, extending on the same level for more than half the length of the cephalothorax and then falling abruptly to the posterior margin, no thoracic groove or depression; eyes, anterior row recurved, a.m.e. separated by less than a diameter, posterior row slightly procurved, p.m.e. largest of the eight, about twice the diameter of a.m.e., separated by less than a diameter, lateral eyes touching; maxille about twice as long as the labium and inclined; sternum triangular, widest between the first coxæ, almost as wide as long, slightly convex, fourth coxæ separated by more than a diameter; legs, 1-2-4-3, quite short, with no spines.

Genotype Allodipœna diance spec. nov.

The genus Allodipona differs from the genus Dipona by the small anterior median eyes and the quite different quadrangle. It differs from the genus Theridion by the high cephalic portion, the large posterior median eyes, the convex sternum and the relatively short legs.

Allodipœna dianæ spec. nov.

Figures 1, 2, 3, 4

Female. Length, 1.5 mm., ceph. 0.6 mm., abd. $0.8 \mathrm{~mm}$. long, $1.2 \mathrm{~mm}$. wide.

Cephalothorax pale greenish-yellow with a large median shield-shaped dark spot that anteriorly is carried by curved lines to the lateral eyes, three-quarters as wide as long, anterior margin broad, cephalic portion high and extending on the same level for more than half the length of the cephalothorax and then falling abruptly to 
the posterior margin, no thoracic groove; eyes, anterior row recurved, a.m.e. convex, diurnal, separated by about a diameter and from a.l.e. by a little less, a.l.e. smaller than a.m.e., posterior row procurved, p.m.e. a broad oval, largest of the eight, heavily ringed with red, separated by less than a diameter and from p.l.e. by fully a diameter and a half, lateral eyes touching, p.l.e. larger than a.l.e.; quadrangle wider in front and higher than wide; clypeus vertical, and not as high as the quadrangle; mandibles vertical and weak; labium dark, wider than long; maxilla pale, about twice as long as labium and inclined so that the tips are almost touching; sternum pale, triangular, almost as wide as long, $(2.5: 3.0)$, widest between the first coxæ, convex, fourth coxæ separated by more than a diameter; abdomen wider than long, white, with a large dark basal spot and a pair of small dark, widely separated dots on the posterior half, wide dark lateral stripes which converge at the spinnerets, abdomen smooth with no hairs or bristles, venter pale; legs, 1-2-4-3, I right missing, quite short, pale, femora with a wide distal dark band, more distinct on the posterior pairs, I and II tibiæ with 3 dark ventral spots, metatarsi with 2 ventral spots, no spines, but rows of colorless hairs, longest on the posterior pairs; epigynum, two dark sacs beneath the surface, separated by less than a diameter.

Male. Length, $1.0 \mathrm{~mm}$.

Cephalothorax pale brown, with no dark marks found in the female, anterior margin little more narrowed than in the female, cephalic portion high, almost as wide as long, no thoracic groove or depression, but a few long bristles on the median line; eyes more closely grouped than in the female, anterior row recurved, eyes equidistant, a.m.e. separated by less than a diameter, posterior row almost straight, eyes equidistant, p.m.e. largest of the eight, surrounded by red, separated by about half a diameter, lateral eyes on a common tubercle; quadrangle narrower in front and higher than wide; clypeus about as high as quadrangle; mandibles long and narrow; labium wider than long, fused to the sternum; maxillæ and the sternum as in the female; abdomen oval, two- 
thirds as wide as long, pale yellow with a vague gray median stripe on the posterior half, with scattered long bristles, venter pale, with the fold only slightly anterior to the middle; legs, IV pair missing, pale, with no spines but rows of hairs; palpus, left palpus missing, not as long as the cephalothorax, very simple and best understood from the figure.

Holotype $q$ Puerto Rico; Luquillo Mountains, 3,000 feet, July 1944 (Beatty).

Allotype o ${ }^{\star}$ Puerto Rico ; Luquillo Mountains, 3,000 feet, July 1944 (Beatty).

The male and female differ in size, shape and color markings, but they probably belong together as they have the same three structural characters that are unusual in the Theridiidæ, the posterior median eyes the largest, the convex sternum and the relatively short legs. The female is quite conspicuous with the distinct dark markings on the cephalothorax and the abdomen, and the abdomen much wider than long.

\section{Family Argiopide}

Genus Tetragnatha Latreille 1804

Tetragnatha parva spec. nov.

Figures 5, 8

Male. Length, $3.0 \mathrm{~mm}$., without mandibles, ceph. 1.1 $\mathrm{mm}$. long, $0.8 \mathrm{~mm}$. wide, abd. $2.0 \mathrm{~mm}$. long, $0.6 \mathrm{~mm}$. wide.

Cephalothorax a deep yellow, anterior margin little narrowed, cephalic portion slightly raised, no thoracic groove but a slight transverse depression; eyes cover the anterior margin, each eye heavily ringed with black, anterior row slightly recurved, a.m.e. separated by less than a diameter, a.l.e. very small, posterior row recurved, eyes subequal with a.m.e., p.m.e. separated by little more than a diameter and from p.l.e. by about a diameter and a half, lateral eyes on separate tubercles that touch at the base but the eyes are separated by more than a diameter of p.l.e.; quadrangle narrower in front and wider behind than high; clypeus almost wanting below a.m.e.; mandibles porrect, basal two-thirds swollen, with a sharp tooth or cusp at the end of the swollen area, fang groove 
oblique, upper margin with three sharp teeth near the base of the fang, followed by a much smaller tooth, lower margin with one small tooth opposite the group of three teeth on the upper margin, fang long and curved; labium pale, about as wide as long, tip rebordered; maxilla pale, two and a half times as long as the labium, sides parallel; sternum pale brown, triangular, widest between the first coxæ, pointed between the fourth coxæ; abdomen pale, with a darker branched median stripe, darker at the tip than at the base, about three times as long as wide, cylindrical, venter pale, spinnerets at the tip; legs, 1-2-4-3, anterior pairs much longer than the posterior pairs, pale, distal joints darker, no spines and few hairs; palpus longer than the cephalothorax, basal joints white, tibia very little longer than the patella, palpus of the usual Tetragnatha type, paracymbium about reaches the tip of the bulb, embolus rests on the conductor that is as long as the cymbium.

Holotype $\sigma^{\pi}$ Puerto Rico; Luquillo Mountains, 3,000 feet, July 1914 (Beatty).

Paratype $0^{\star}$ Puerto Rico; Luquillo Mountains, 3,000 feet, July 1944 (Beatty).

Tetragnatha parva is much smaller than the other species of the genus found in the Caribbean. Like T. tenuissima Cambr., it has no spines on the legs, but the most unusual character is the few teeth on the margin of the fang groove, with the absence of the "large tooth", usually found on the upper margin. The tubercles of the lateral eyes touch at the base, but the eyes are distinctly separated.

Family Salticide

Genus Agobardus Keyserling 1884

Agobardus blandus spec. nov.

Figure 6

Female. Length, $3.0 \mathrm{~mm}$., ceph. $1.6 \mathrm{~mm}$. long, $1.2 \mathrm{~mm}$. wide, abd. $1.6 \mathrm{~mm}$. long, $1.2 \mathrm{~mm}$. wide.

Cephalothorax, a dark shining brown with a pale median stripe from the thoracic groove to the posterior margin, in life this stripe probably covered with white 
scales as a few remain, a few white scales about the eyes, a narrow marginal stripe of white scales from the second coxæ to the posterior margin, cephalothorax high, sloping gradually from the groove to the posterior margin, anterior margin very little narrowed, thoracic groove short in a semi-circular depression between the dorsal eyes; eyes, anterior row covers the margin, recurved by the upper margins, a.m.e. very large, separated by a line, a.l.e. less than a radius of a.m.e. and separated from them by a line, second row of eyes midway between the first and third rows, dorsal eyes on the extreme margin of the carapace and slightly larger than a.l.e.; quadrangle same width in front as behind; clypeus about wanting below a.m.e., with a fringe of white hairs and a long recurved bristle between the a.m.e.; mandibles dark brown, vertical, no hairs or scales, fang groove short and oblique, upper margin with two small teeth, lower margin with a plate with two cusps, fang short; labium brown, slightly longer than wide, tip rebordered; maxilla pale, almost twice as long as labium; sternum pale, almost as wide as long, (4.0:4.5), first coxæ separated by more than a diameter, fourth coxæ almost touching; abdomen oval, about two-thirds as wide as long, pale, with a pair of wavering dark stripes which end at a narrow curved cross band just above the spinnerets, and a pair of lateral dark stripes which join the median pair above the cross bar and reach the spinnerets, the entire abdomen covered with short white hairs, venter pale with a pair of widely separated black spots just anterior to the spinnerets, spinnerets long and closely grouped; legs, I pair missing, 4-3-2, pale, II femur with a large prolateral dark spot, posterior femora with a dark basal dorsal spot, and a distal dark ring, spines, II pair, patella, prolateral, 1, tibia, ventral, 2-2-2, prolateral, 3, retrolateral, 1, metatarsus, ventral, 2-2, basal pair very long, lateral, 2; epigynum only faintly chitinized, a pair of circular sacs beneath the surface, not quite touching, best understood from the figure.

Holotype + Puerto Rico; Luquillo Mountains, 3,000 feet, July 1944 (Beatty). 
Agobardus blandus is probably related to Agobardus tetuani (Petr.) (Emathis), from Tetuan Mountain, near Jayuya and also from Rio Piedra, Puerto Rico. The latter species has five cusps on the plate of the fang groove, and the cephalothorax has a large pale lateral spot each side. The abdominal dark marks also, differ. It is not impossible, that each mountain has a distinct species of this genus.

\section{Genus Habronattus F.O.P.-Cambridge 1901} Habronattus pretiosus spec. nov.

Figures 7, 9

Male. Length, $3.6 \mathrm{~mm}$., ceph. $2.0 \mathrm{~mm}$. long, $1.5 \mathrm{~mm}$. wide, abd. $1.6 \mathrm{~mm}$. long, $1.1 \mathrm{~mm}$. wide.

Cephalothorax dark brown, ocular area thickly covered with white iridescent scales and longer dark bristles with the posterior margin between the dorsal eyes sharply defined by a dark band, curved lateral stripes of the white scales from the dorsal eyes to the posterior slope where they end abruptly, a broad marginal stripe of white scales ending abruptly above the second pair of legs, cephalic portion high, gradually rising to the thoracic groove when it falls gradually until about one-fifth from the posterior margin where it drops rapidly, widest posterior to the second pair of legs, thoracic groove short, in a semicircular depression, in a line between the dorsal eyes; eyes, anterior row recurved, so that the upper margins form a straight line, a.m.e. separated by a line, and from a.l.e. by a little more, a.l.e. about one-half a diameter of a.m.e., eyes of second row very small and midway between the first and third rows, dorsal eyes slightly larger than a.l.e.; quadrangle slightly wider behind than in front; clypeus about as wide as a diameter of a.m.e., thickly covered with white scales which join with the marginal stripe that ends at the second pair of legs; mandibles brown, small, vertical, fang groove very short, upper margin with three contiguous teeth, lower margin with one tooth; labium brown, as wide as long; sternum oval, margins dark and center pale, I coxæ separated by less than a diameter, IV coxæ touching, the dark area with long white hairs; 
abdomen oval, with a white basal band that continues as lateral stripes to the spinnerets, a pair of dark stripes that unite above the spinnerets with inner margins irregular, leaving a pale median stripe, venter with three dark stripes united in front of the spinnerets by a short dark band; legs, 3-4-1-2, I pair heaviest, dark brown, with a distinct prolateral darker stripe on the femur, patella and tibia, the dark area on the femur flattened, II, III and IV pairs pale, with dark rings at the base and distal ends of femur and tibia, patella with a pair of dark spots near tip, spines, I pair, patella, 0, tibia, ventral, 2-2,lr, metatarsus, ventral, 2-2, III and IV tibiæ with a dorsal, basal spine and a ventral retrolateral spine near the base; palpus not as long as cephalothorax, femur and patella with white iridescent scales on the dorsal side, tibia and cymbium dark, with coarse dark hairs, tibia not as long as patella, tibial apophysis dark, shining and pressed close to the cymbium, palpal organ of the usual type with the outer process longer and starting from the side and ending in a slender tip at the end of the cymbium, the inner process heavier, starts about the middle of the bulb and ends about opposite to its origin.

Female. Length, $3.0 \mathrm{~mm}$., ceph. $1.6 \mathrm{~mm}$. long, $1.1 \mathrm{~mm}$. wide, abd. $1.9 \mathrm{~mm}$. long, $1.2 \mathrm{~mm}$. wide.

Cephalothorax dark ehestnut-brown, ocular area thinly covered with golden iridescent scales which continue in parallel lateral stripes from the dorsal eyes and end abruptly above the posterior margin, these lateral stripes are shorter than in the male, marginal stripe of white scales on the posterior margin only, cephalothorax high, sides not as much rounded as in the male, thoracic groove short, in a semi-circular depression; eyes as in the male; clypeus equals about half a diameter of a.m.e., brown, with scattered golden scales, palpus, femur and patella covered with white scales; mandibles brown, vertical, mouth parts as in the male; sternum brown; abdomen with three dark triangles, one median and basal, and the other two lateral, just posterior to the middle, posterior to the basal triangle, a transverse pale band of white iridescent scales, the median area between the dark lateral 
triangles pale brown, with vague chevrons on the posterior half, ventor pale with a large dark rectangle from the fold to the spinnerets; legs, 3-4-1-2, pale, femora with ventral distal and basal dark spots, spines as in the male; epigynum with the parts only lightly chitinized, a pair of widely separated spermatheca beneath the surface in the posterior part, anteriorly, a pair of oblique oval sacs with a small dark spot at the tips which probably are openings, middle area a circular depression, best understood from the figure.

Holotype o $0^{\pi}$ Puerto Rico; Luquillo Mountains, 3,000 feet, July 1944 (Beatty).

Allotype $q$ Puerto Rico; Luquillo Mountains, 3,000 feet, July 1944 (Beatty).

Paratypes o 2 ㅇ Puerto Rico ; Luquillo Mountains, 3,000 feet, July 1944 (Beatty).

The male and female Habronattus pretiosus have several characters in common as do several other species of the genus. Both have the eye area covered with scales, white in the male and golden in the female; the legs have the same dark ventral spots on the femora but only the male has the prolateral surface of the first femur flattened and covered with white scales. The lateral stripes of iridescent scales on the cephalothorax that end abruptly on the posterior slope are very conspicuous and are common to both male and female. The flattened area on the first femur of the male has not been seen before in the genus and is very conspicuous.

\section{Literatere Cited}

Banks, N. 1896. New North American Spiders and Mites. Trans. American Ent. Soc., 23, pp. 57-77.

Bryant, Elizabeth B. 1947. Spiders of Mona Island. Psyche, vol. 54, pp. 86-99, 1 plate.

Petrunkevitch, Alexander. 1929-1930. The Spiders of Porto Rico. Trans. Conn. Acad., pt. 1, 30, pp. 1-158, 150 figs.; pt. 2, 30, pp. 159-358, 240 figs., pt. 3, 1930, 31, pp. 1-191, 168 figs. 


\section{Explanation of Plate}

Fig. 1. Allodipona diance spec. nov., female, dorsal.

Fig. 2. Allodipœna diance spec. nov., epigynum.

Fig. 3. Allodipœna diance spec. nov., male, dorsal.

Fig. 4. Allodipœna diana spec. nov., right palpus.

Fig. 5. Tetragnatha parva spec. nov., left mandible, ventral.

Fig. 6. Agobardus blandus spec. nov., epigynum.

Fig. 7. Habronattus pretiosus spec. nov., epigynum.

Fig. 8. Tetragnatha parva spec. nov., left palpus.

Fig. 9. Habronattus pretiosus spec. nov., left palpus. 


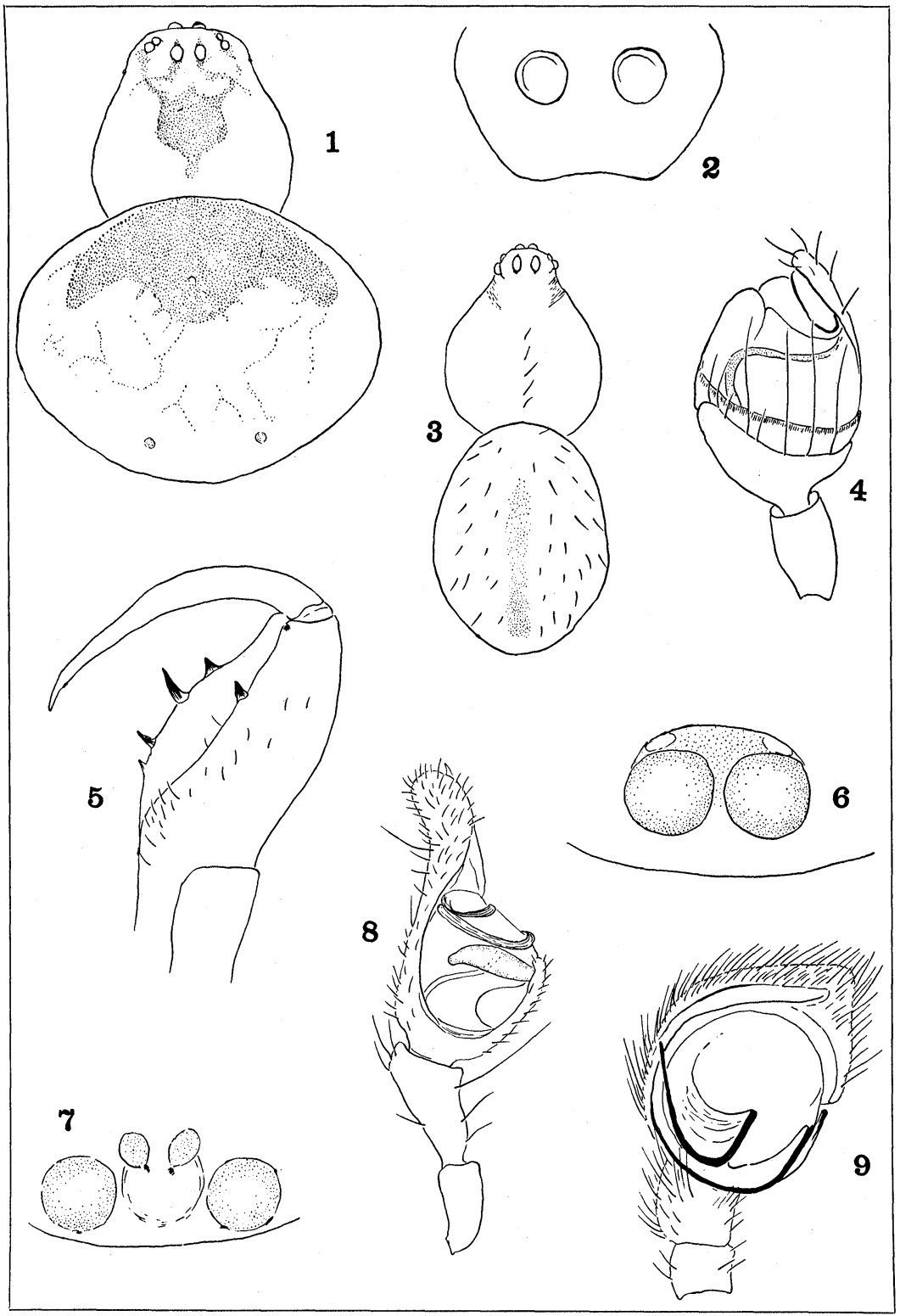

Bryant-SPIDERs From Puerto Rico 

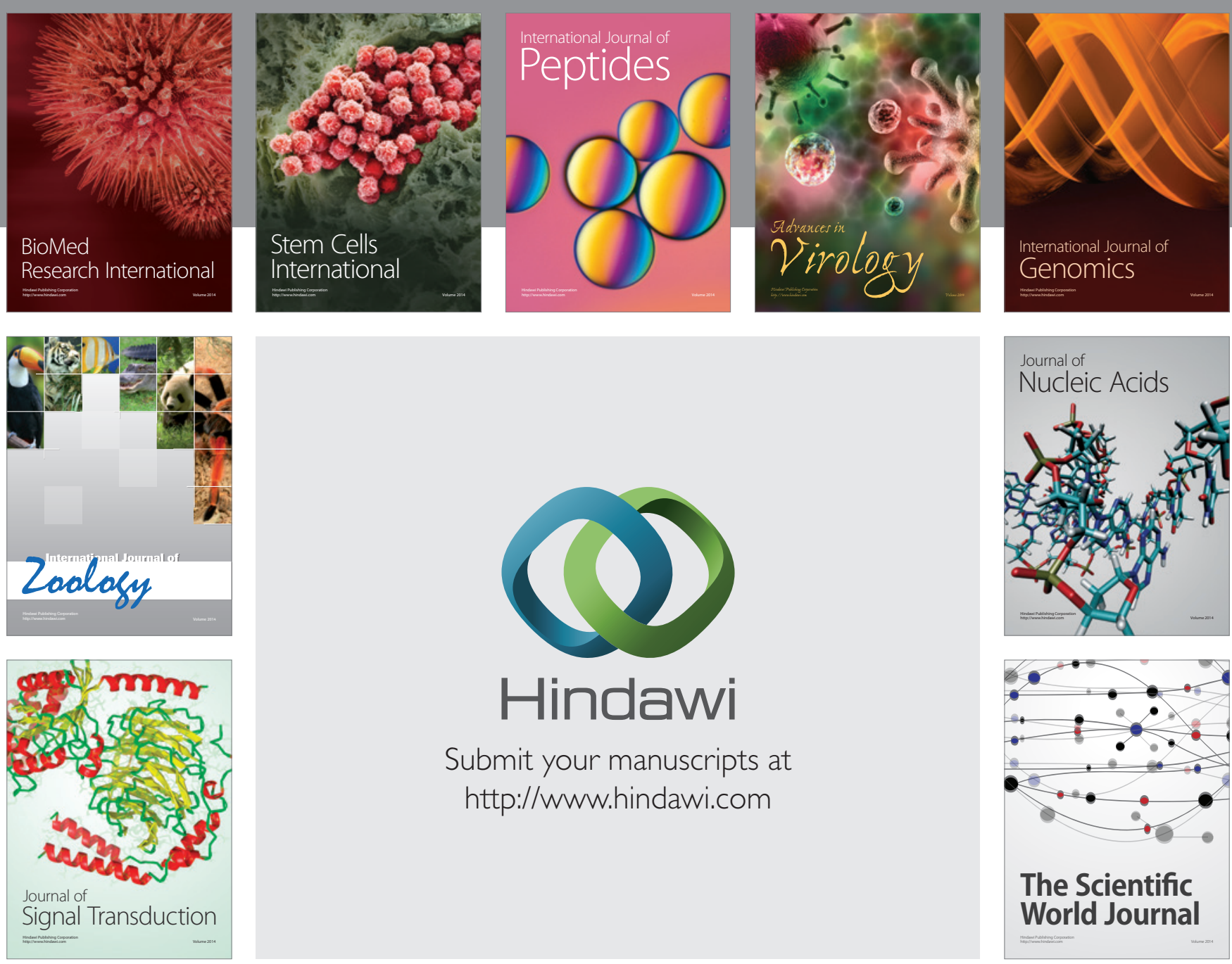

Submit your manuscripts at

http://www.hindawi.com
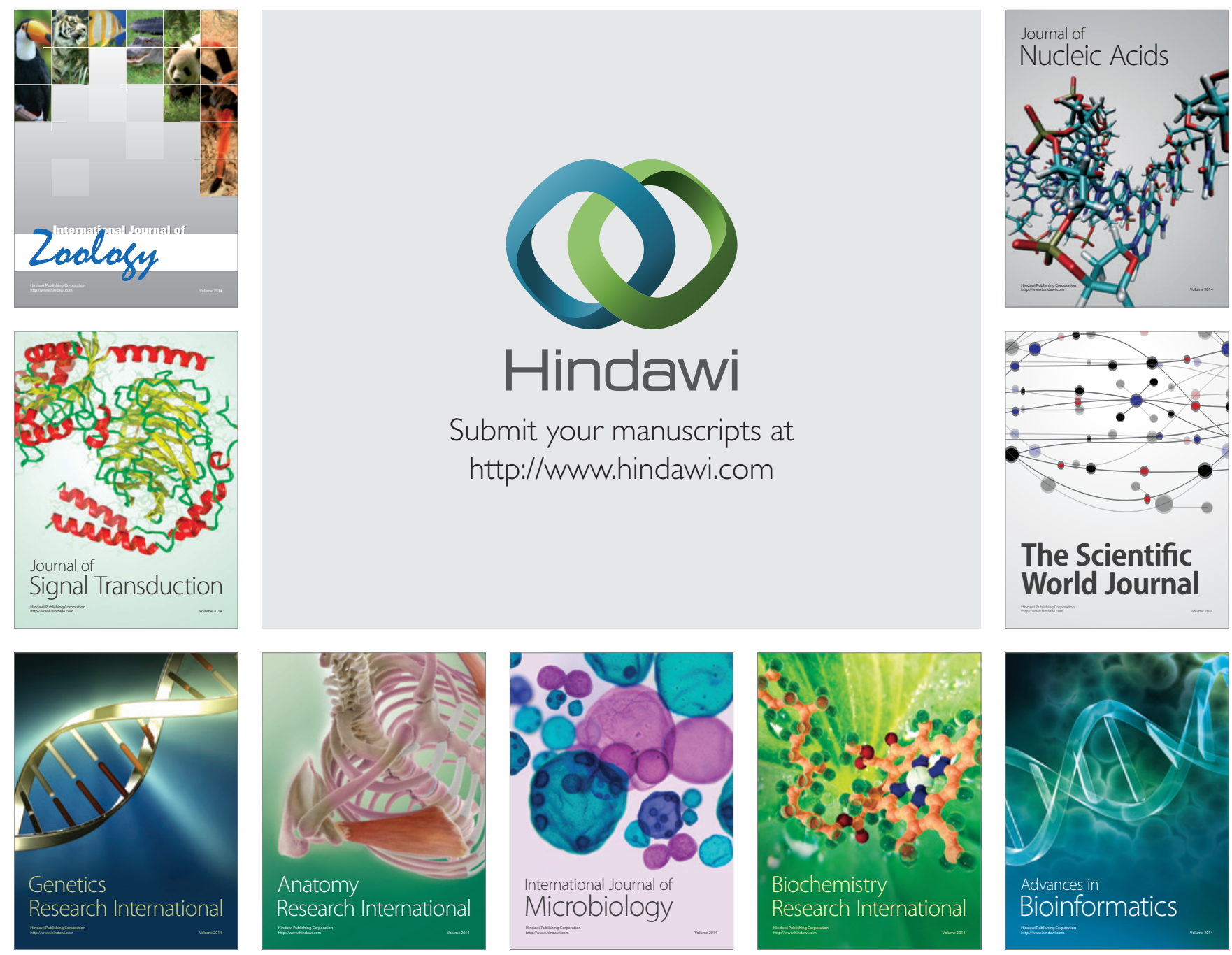

The Scientific World Journal
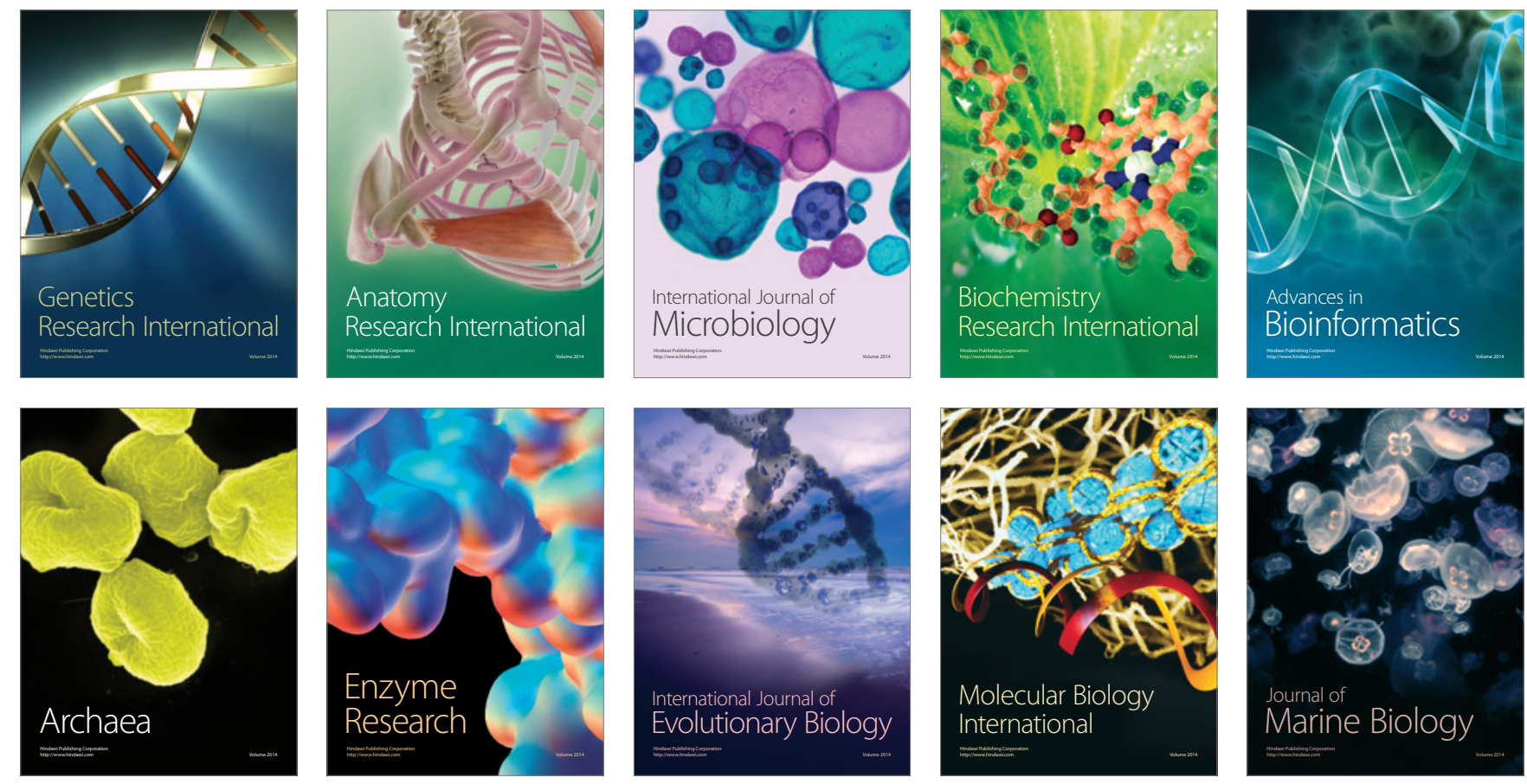